\title{
Introduction
}

The generation which commences a revolution can rarely complete it. -Thomas Jefferson, 1823

Today we routinely hear Americans declare that the republic is in a state of existential crisis. In news media, commentators opine that even the most finely wrought descriptive words cannot begin to capture the enormity of the crisis. The emergence of the COVID-19 pandemic, moreover, has greatly magnified these related crises. For purposes of clarification, then, it may be useful to frame the problems of the moment as paradigmatic in nature, as a system-wide crisis consisting of a set of concomitant, interconnected crises. Crises over the status of truth in public discourse; crises over corporate corruption in a post-Citizens United world; crises over the country's unconstitutional forever wars; crises over a seemingly irreversible planetary ecocide led by the United States; crises over a neoliberal educational regime whose defining feature appears to be the civic and democratic demoralization of America's public schools; and finally, crises over a combined sense of hopelessness and what might be called outrage fatigue. A rapid intensification of these political and cultural contradictions seems to be the hallmark of our era. ${ }^{1}$

${ }^{1}$ The paradigmatic analysis here is indebted to many authors, below I name a few. Thomas S. Kuhn's The Structure of Scientific Revolutions. Chicago: University of Chicago Press, 1996 helps us to map structural transformations in many arenas. Kuhn's insight that

(C) The Author(s) 2020

K. T. Burch, Jefferson's Revolutionary Theory and the Reconstruction of Educational Purpose, The Cultural and Social Foundations of Education, https://doi.org/10.1007/978-3-030-45763-1_1 
On the educational front, teacher strikes in Arizona, West Virginia, Kentucky, Oklahoma, Colorado, North Carolina, and in the city of Chicago, among other locales, speak at once to the shameful conditions that teachers face and to the hope that their underlying causes may soon be addressed. From a paradigmatic standpoint, it seems as if the very purposes of education that neoliberalism has imposed upon the nation's schools in the last few decades itself constitutes one of our deepest systemic problems and challenges. Since the public schools have always been in the business of modeling some form of identity or another, as they necessarily must, the question arises: As possible models of human identity toward which the schools might aspire to educate the young, should they continue along the path charted by neoliberalism and concern themselves primarily with reproducing versions of Homo Economicus? Or, should the schools recover their civic purposes and concern themselves primarily with reproducing versions of Homo Civicus? ${ }^{2}$

This book is an invitation to think through these questions and problems from a Jeffersonian perspective. It makes the case that a critical engagement with the most radical dimensions of Jefferson's educational philosophy—what I am calling his revolutionary theory—can establish a

paradigm shifts historically have occurred when "anomalies" and "contradictions" begin to accumulate within any given explanatory model/paradigm, suggests that we are presently on the cusp of such a transformational shift. For a much needed account of how the American warfare state is destroying the very conditions that make democracy possible, see Tom Engelhardt's A Nation Unmade by War. Chicago: Haymarket Books, 2018. My analysis is also indebted to David Blacker's What's Left of the World: Education, Identity and the Post-Work Political Imagination. London: Zero Press, 2019. Blacker's assessment of our educational future is bleak, and I think this reinforces the need for paradigmatic rather than incremental change. For an incisive look at the dismal state of civic education today, see Michael Rebell's Flunking Democracy: Schools, Courts and Civic Participation. Chicago: University of Chicago Press, 2018. As both an education litigator and professor at Teachers College, Columbia University, Rebell effectively gives the United States an "F" when it comes to providing a decent civic education to the nation's youth. For a powerful and poetic reflection on the irreversibility of climate warming and its consequences, see David Wallace-Wells's, The Uninhabitable Earth: Life After Warming. New York: Tim Duggan Books, 2019.

${ }^{2}$ It is common for authors in various disciplines to employ the trope of "Homo Economicus/Homo Civicus" as a way to theorize how the ongoing tensions between capitalist and democratic moral imperatives are manifest within individuals in educational and other social spheres. One of the best discussions of this trope, including the destructive effects of neoliberalism on education today, can be found in Wendy Brown's, Undoing the Demos: Neoliberalism's Stealth Revolution. Brooklyn: Zone Books, 2015. 
rational basis upon which to reestablish both the civic purposes of public education and the quality of our democracy. I believe that the educational challenges posed by the predicaments outlined above can be most intelligently met-and remedied-when interpreted in relation to the democratic-revolutionary tradition launched by the American Revolution. I further contend that if teachers in particular were to develop a keener appreciation for what is most "revolutionary" about the American Revolution, it would not only illuminate many contemporary predicaments, but its remembrance could serve as a resource for envisioning and working toward a more just and democratic America. In this regard, I am increasingly convinced that however well-intentioned our efforts on behalf of educational reform, they are bound to fail to the degree they are symbolically and normatively untethered from the nation's democraticrevolutionary tradition. We turn to Jefferson today to re-tether ourselves to this forgotten tradition. ${ }^{3}$

Perhaps the most cogent expression of the radical democratic tradition of the American Revolution is Thomas Jefferson's revolutionary theory. ${ }^{4}$ In the following chapters, the goal is to articulate how a better grasp of Jefferson's revolutionary vision can serve as a kind of moral and pedagogical compass for both restoring and redirecting the democratic civic purposes of public education.

In broad conceptual strokes, the idea of permanent revolution signifies a positive cultural orientation to conflict and to political renewal. ${ }^{5}$ Whatever terminology we use, whether "revolutionary theory" or theory of "permanent revolution," the theory's defining quality for Jefferson was both processual and moral (moral because it contained a democratic telos,

\footnotetext{
${ }^{3}$ For a trenchant and wide-ranging account of Jefferson's overlooked radical side, see Richard Matthews, The Radical Politics of Thomas Jefferson: A Revisionist View. Lawrence, KS: University of Kansas Press 1986.

${ }^{4}$ The conceptual validity of this claim is rooted in the following three sources. More recently, Michael Hardt, in his Thomas Jefferson: The Declaration of Independence. London: Verso, 2007, makes a strong case for validating Jefferson's revolutionary credentials. Tellingly, Hardt's book is part of a series by Verso Books on revolutionary thinkers. I was surprised to see Jefferson included in such a series, alongside books on the revolutionary thought of Mao, Ho Chi Minh, Gramsci, Robespierre, Guevara, Lenin, Zizek, and others. Dan Sisson's, The Revolution of 1800: How Jefferson Rescued Democracy from Tyranny and Faction-And What It Means Today. San Francisco: Berrett-Koehler, 2013, affirms Jefferson's claim that the election of 1800 should indeed be properly framed as a revolution. Hannah Arendt's On Revolution, New York: Penguin Classics, 1963, is widely recognized to have fortified Jefferson's status as a revolutionary thinker.

${ }^{5}$ Hardt, see "Thomas Jefferson, Or, The Transition of Democracy," vii-xxv.
} 
or end-in-view). The theory can be posited interchangeably as a revisionary state of being, a conceptual framework, a discourse, and importantly, as a form of democratic rhetoric. This rhetorical dimension is crucial to bear in mind, for Jefferson deployed the theory rhetorically to serve as a conduit for channeling the mythopoetic Spirit of $76 .^{6}$ The function of the theory as a form of rhetoric was not to describe the static and finished dimensions of reality (to the extent any exist), but rather to theorize historical reality in all of its kaleidoscopic permutations.

Because of the democratic and inter-generational teleological foundation of Jefferson's revolutionary theory, it aptly symbolizes that which is most revolutionary about the American Revolution. ${ }^{7}$ The "most revolutionary" quality of the nation's founding event did not rest, for example, on the fact that the American patriots successfully seized state power from the British. The most revolutionary dimension of the American Revolution was the idea that its success would depend on its moral values being enacted and reenacted, generation after generation. ${ }^{8}$ Jefferson repeatedly observed that the ultimate success, or vindication, of the American Revolution would hinge on whether subsequent generations of Americans would have the capacity and willingness to re-imbue the meaning of the Spirit of 76 into novel historical circumstances, unforeseeable circumstances that would require politically and culturally inventive efforts to refresh the meaning of its core values. 9

The ultimate status of the American Revolution, then, would depend on the ability of the American people to learn the art of revising the meaning of that Spirit as new conditions and new needs developed over successive generations. According to this historiographic perspective, it was not the formal structures of US government (e.g., checks and balances,

${ }^{6}$ I use the term "mythopoetic" as a designator for the Spirit of 76 because I think it captures its mythological and poetic character (note: the etymology of poiesis (Gr.) means "to create"). For more on the meaning of poiesis, see Jim Garrison, Dewey and Eros: Wisdom and Desire in the Art of Teaching. New York: Teachers College Press, 1997, xv, 8-9, 24, 49, 71, 88 .

${ }^{7}$ In Greek, telos means "end," thus, in this context, teleological refers to the ultimate purpose of Jefferson's theory: that being, the perpetual transition toward deeper levels of democratization.

${ }^{8}$ Hardt, "Transition and Democracy," xv-xxi.

${ }^{9}$ For a concise formulation of this Jeffersonian principle, consult Annette-Gordon Reed's and Peter Onuf's magisterial, "Most Blessed of the Patriarchs": Thomas Jefferson and the Empire of the Imagination. New York: W. W. Norton \& Company, 2016, 235. It is worth noting that the "Spirit of 76 " is indexed ten times, a measure of its centrality to Jefferson's thought. 
election cycles) that was most significant about the American Revolution, as important as they were. As suggested, what was most revolutionary was the historical emergence of a Spirit \& Idea, a secularized religious project that gave birth to the nation's democratic-revolutionary tradition. This mythical terrain, as a meaning narrative, represented a sharp discontinuity from ancient regimes and their monarchies, standing armies and entrenched aristocratic elites. Yet, we could also trace the discursive lineage of this spirit to ancient democratic Athens, to the classical republican tradition, and to the radical democratic strand of the Enlightenment tradition. ${ }^{10}$ For Jefferson, this new animating spirit seemed to contain a "mythopoetic" quality, a moral geography, if you will, capable of summoning up within individual's emotional intensities and devotions to a set of democratic moral ideals. In the chapters ahead, I make the case that Jefferson's discourse of permanent revolution can be interpreted as a hermeneutic through which the symbolic field of meanings sequestered within the Spirit of 76 can be channeled and empirically realized. ${ }^{11}$

Unfortunately, however, the popular image of the American Revolution that most of us pick up along the way is rooted in an assumption that the revolution was, above all, a finite event synonymous with, and reducible to, the military phase of the conflict (1775-1782). Jefferson's revolutionary theory explicitly rejects this mechanical conception of the founding. His theory assumes instead that our revolution should not, ultimately, be imagined as something finished or complete, but should rather be imagined as a perpetually unfinished historical project. In other words, the popular image of the American Revolution taught in the schools tends to conflate and confuse a finite war with a set of inter-generationally embodied moral purposes. One of the essential features of Jefferson's revolutionary thought is that it highlights the significance of this conceptual distinction.

Turning to the curricular implications of Jefferson's revolutionary theory, I argue that its defining elements point directly to the importance of developing in students' their capacities to revise, to improvise, to experiment, to rebel, to remember, and to become mindful of political

\footnotetext{
${ }^{10}$ For a comprehensive intellectual history of the American Revolution, republican ideology, and its enlightenment-informed emergence, see Jonathan Israel, The Expanding Blaze: How the American Revolution Ignited the World, 1775-1848. Princeton: Princeton University Press, 2017.

${ }^{11}$ Philosopher Richard Bernstein has recently brought his analytical acumen to the American Revolution in his Why Read Hannah Arendt Now. London: Polity, 2018. See, "The American Revolution and the Revolutionary Spirit," 103-116.
} 
ambition and greed in all its guises. A Jeffersonian-inspired redirect of curricular purpose today, would certainly mean, among other things, a restoration of the centrality of both civic education and the humanities into the K-12 curriculum. Jefferson valued these traditions because he understood that the foundational pillars of a republican civic identityfreedom, truth, reason, civic engagement, to name a few-were moral capacities whose development depended in no small measure on the tradition of the humanities. Although Jefferson was not the only founder to link the survival of the republic to the project of educating the intelligence and virtue of the American people, he was perhaps the most eloquent in establishing the crucial linkages between education and the ongoing nature of the revolution. It is on these moral and curricular grounds, that I recruit Jefferson today as an iconic, if controversial resource for providing insight into the ongoing task of educating virtuous democratic citizens and societies.

In writing the book, I am mindful that, for some readers, Jefferson's racist pronouncements and practices may well nullify any prospect that his theories could have contemporary relevance. It is not my intention in this book to condemn or to praise Jefferson so much as it is to grasp what he was trying to "get at" in formulating his revolutionary thought. Rather than ignoring the growing number of critical perspectives on the slave-holding enlightener from Monticello, I frame Jefferson as a synecdoche of the nation, as a figure who continues to stand for and symbolize the ideals, contradictions, hopes, and tragedies gyrating at the nucleus of American political culture. ${ }^{12}$ As many authors before me have observed, to inquire into Jefferson, is also to inquire into the often baffling, contradictory, ambiguous, and tragic qualities of the American experience itself. An examination of these problematic facets of Jefferson's life reveals some stark reminders. First, we must recognize the danger of uncritically appropriating the thought of any eighteenth-century figure for purposes of interpreting twenty-first century conditions. Perhaps more importantly, we should never overlook Jefferson's most egregious shortcoming: His failure, despite his democratic sympathies, to promote a multi-racial image of national identity for America's future. ${ }^{13}$

${ }^{12}$ Peter Onuf/Jan Lewis, "American Synedoche: Thomas Jefferson, as Image, Icon, Character and Self." In The Mind of Thomas Jefferson, ed. Peter Onuf. Charlottesville: University of Virginia Press, 2012, 85-94.

${ }^{13}$ Reed/Onuf, Blessed are the Patriarchs, Preface, 11-25. This work is groundbreaking in large part because the authors, while unflinching in their criticisms of Jefferson, are also 


\section{The Style and Structure of The Book}

The book has been influenced by the style of writing adopted by two giants in my disciplinary field: John Dewey and George Counts. As chief architects of the twin disciplines of philosophy of education and the social foundations of education, Dewey and Counts frequently deployed a genre of writing that combined a critical analysis of American power relations with a healthy dose of philosophical reflection. Dewey biographer Alan Ryan, for example, describes many of his essays as "lay sermons." 14 This book seeks to extend that tradition. Ryan defines the lay sermon as a genre of writing located at the intersection where philosophical analysis meets the advocacy of new public policies, and where professional academics, through their writing, initiate meaningful conversations about current affairs with the broader reading public. Without engaging in conceptual overreach, I believe that, in important respects, the lay sermon can be regarded as a form of rhetoric that bears strong, albeit secular, resemblances to the American jeremiad tradition. It is for this and other reasons, explained below, that the book is organized according to the jeremiad's three-part thematic structure. I adopt this format because the telos, or end-in-view, of Jefferson's revolutionary theory recapitulates, in both substance and form, this uniquely American form of rhetoric.

As Sacvan Bercovitch, David Murphy, David Howard-Pitney, and George Shulman have articulated, all types of jeremiadic texts-from the speeches of Jonathan Edwards and Frederick Douglass to Eugene Debs and Martin Luther King-partake of the same thematic structure, despite other differences in moral and ideological substance. ${ }^{15}$ The structure of the Puritan rhetorical trope unfolds in three sequences. In the first

cognizant of his pedagogical value as an object of study. It's not about elevating Jefferson or tearing him down, rather his value lies in understanding his contested role throughout American history in the formation of national identity.

${ }^{14}$ See Alan Ryan, John Dewey and the High Tide of American Liberalism. New York: W. W. Norton \& Company, 1995, 265-266.

15 Although the literature is vast on the jeremiad style of rhetoric, my own understanding of it is particularly indebted to the following authors: Sacvan Bercovitch The American Jeremiad. Madison: University of Wisconsin Press, 1986; Andrew R. Murphy, Prodigal Nation: Moral Decline and Divine Punishment: From New England to 9/11. Oxford: Oxford University Press, 2011; David-Howard-Pitney, African-American Jeremiad: Appeals to Justice in America. Philadelphia: Temple University Press, 2005; George Shulman, American Prophecy: Race and Redemption in American Political Culture. Minneapolis: University of Minnesota Press 2018. 
sequence, the speaker or writer reminds their audience about the rich significance and promise of their agreed-upon social covenant. In the second sequence-the declension - the speaker excoriates congregants for having so deplorably lost sight of their founding vision. Here, the "chosen people" risk botching their lovely experiment unless prophetically called back to renew the values of their original vision. In the third sequence, the audience is offered a redeeming vision of renewal in which their moral devolution can be turned around, but only if a new connection is forged with the forgotten values that once defined their community.

In the context of this book, then, the "promise" is the secular promise of Jefferson's democratic-friendly revolutionary theory, upon whose creative execution the fulfillment of the revolution depends. The "declension" element comes into play in the chapters ahead as we realize the extent to which the character of today's politics, education, and culture has turned nakedly oligarchic, thereby posing an existential threat to the nation's democratic experiment. As to the future-oriented "renewal" phase, I argue that renewal may come when and if the American people can learn, metaphorically, to pour the old vintage wine of Jefferson's revolutionary theory into newly refashioned, twenty-first century bottles. As our title suggests, this means that Americans will be successful today in reconstructing the purposes of education beyond the parameters of neoliberalism, to the degree that we can recover the moral impulses that animated Jefferson's educational vision. ${ }^{16}$

There is another tradition related to the jeremiad that also colors the book's approach. Here I am referring to the democratic strand of the American political tradition. I write as a philosopher of education indebted to the traditions of Socratic and Freirean pedagogy, but also to the democratic strands of the American political tradition. In several chapters, for example, I link Jefferson's animus against standing armies to figures like George Washington, Dwight Eisenhower, and Martin Luther King, Jr., who reflected similar beliefs in their writings. In other chapters, I argue for a recovery of the relevance and meaning of the Declaration of Independence through an examination of Abraham Lincoln's prophetic

\footnotetext{
${ }^{16}$ While Jefferson's educational vision was limited in important ways, as will be discussed in Chapter 3, I maintain that it's still useful today in the sense that it underscores the fundamental civic purposes of education, and it is precisely this quality that requires recovery in our times.
} 
writings on the Declaration. In other chapters, I situate Jefferson's educational and revolutionary thought alongside the work of John Dewey and George Counts. Thus, I write within the American political tradition, a tradition that I believe still retains a great deal of potential power to transform things for the better, provided, of course, that we reframe these strands in the right way. Among other things, then, the book is an attempt to recover the radical democratic potential of the nation's rich but all too often neglected political tradition.

What makes the book particularly distinctive, then, is that it does not stop after providing an in-depth examination of Jefferson's revolutionary theory in its eighteenth- and early nineteenth-century contexts. It proceeds beyond this and seeks to apply the insights afforded by Jefferson's theory to the contemporary and future educational scene. No other Jefferson title that I am aware of today occupies this past, present, and future space. Owing to the fact that Jefferson's revolutionary theory contains a strong future-directed trajectory, I believe that it would lose much of its potential transformative power if we were to conceptualize it in isolation from the present and future.

Part I, Promise, covers Chapters 2 through 5. The first chapter defines the essential features of Jefferson's theory. The second chapter discusses its' educational implications and how they might be articulated and mined theoretically for their contemporary significance. In Chapters 4 and 5, I examine the ways in which two influential educational theorists of the twentieth century, John Dewey and George Counts, respectively, provided critical updates to Jefferson's revolutionary thought in the midst of the Great Depression.

Part II, Declension, consists of Chapters 6 through 8. These chapters are anchored in constitutional amendments that Jefferson proposed but were never enacted (namely, no standing armies, freedom from monopolies, and a federal education amendment). The core aim of Part II is to describe, on the one hand, why the failure to enact these three constitutional amendments symbolizes a form of democratic moral declension and, on the other, how the critical spirit underlying each of the proposals can be reignited in classrooms today.

The chapters in Part II are organized in three sections. The first sections establish the historical context of the proposed amendments and discuss the ways in which they fit into and augment Jefferson's theory of 
permanent revolution. The second sections highlight the so-called declension element, that is, how the moral principles and values of the amendments have been virtually eclipsed and overwhelmed by contemporary empirical realities. The third sections of each chapter are renewal-oriented and theoretically experimental, in that they consider how the moral spirit undergirding the respective amendments might be imaginatively retrieved today, both as a means for analyzing the present and for rejuvenating our democratic political imaginations.

Part III, Renewal, consists of Chapters 9 through 11. In this thematic sequence, I begin by restating in capsule form what I take to be the defining revisionary features of Jefferson's theory. The normative aims and future-directed character of the concluding chapters represent an homage to Jefferson's desire for bringing about revolutionary change through the reconstruction of educational purpose. In a contemporary update to Jefferson's spirit of curricular innovation and experimentation, I maintain that the best way for the public schools to meet the evolving needs of American youth would be for them to implement a Jeffersonianinspired reconstruction of educational purpose. What is most needed, I contend, is for the schools to "re-found" their fundamental purposes to better align themselves with that which is most revolutionary about the American Revolution. This final section of the book tells a story about what it would mean to recover these values and to embark upon a journey of moral renewal along several fronts: educationally, politically, and culturally. 